\title{
津波の伝播計算を対象とした 非線形分散長波式の比較
}

\author{
岩瀬浩之 ${ }^{1} \cdot$ 見上敏文 $^{2} \cdot$ 後藤智明 $^{3} \cdot$ 藤間功司 $^{4}$ \\ ${ }^{1}$ 正会員＼cjkstart株式会社エコー 沿岸デザイン本部環境水工部 ( ₹ 221-0052 神奈川県横浜市神奈川区栄町 10-35) \\ 2正会員 株式会社アルファ水エコンサルタンツ 技術部技術 3 課 課長 \\ 正会員 工博 東海大学教授 工学部土木工学科 \\ ${ }^{4}$ 正会員 工博 防衛大学校助教授 システム工学群建設環境工学科
}

\begin{abstract}
いくつかの断面平均および断面積分形の非線形分散長波式から線形分散関係式および孤立波に関する第 1 次 近似解を導いた. 断面平均形の式の孤立波解は，KdV 式の解に比べ急峻な波形になる. 一方，断面積分形の式 は, 比較的幅広な波形となる. 津波のソリトン分裂に関してこの相違は重要である. 本研究では, 線形分散特 性および孤立波形の比較から, そして水理実験と数値解析の比較から津波の数值解析に適切な非線形分散長波 式について考察した，その結果，断面積分形の Peregrine 式または Madson \& Sørensen 式が適切であるという 結論を得た.
\end{abstract}

Key Words : nonlinear dispersive long wave equation, solitary-typed solution, tsunami

\section{1. はじめに}

水面波の非線形性および分散性を考慮した波浪の伝 播·変形を解析する目的で非線形分散長波式が使われるよ うになってきた。 これらの非線形分散長波式は, $\mathrm{KdV}^{1)}$ 式と異なり任意海底形状の 2 次元平面解析を対象とし たものであり，1966 年および 1967 年に発表された Mei \& LéMéhaute 式 ${ }^{2)}$ やPeregrine 式 ${ }^{3)}$ を基礎としたもの である．近年になり，分散項に有限振幅性を考慮した式 として後藤 ${ }^{4)}$ が，そして線形分散特性を改善した式が Madsen \& Sørensen ${ }^{5)}$, Nwogu ${ }^{6)}$, Beji \& Nadaoka ${ }^{7)}$, Cruz et al. ${ }^{8)}$ などにより提案さ扎ており, 沿岸波浪の 変形などにこれらの修正式を利用した数值解析が多数 実施されている.

本研究では, 津波の伝播・変形に適した非線形分散 長波式を検討することを主たる目的として，現在まで 種々の解析に利用されている非線形分散長波式の比較 検討を行う. 津波の伝播・変形に扔いて特徽的なこと は, 深海域でも波数分散現象が起こること，乙して浅 海域の最終的な変形過程において津波がリリトン分裂 を起こしたり波状段波となることである。したがって， 線形分散以外に非線形性と分散性の相互作用まで踏み 込んだ考察が必要である.

なお，弱非線形性そして弱分散性を仮定した非線形 分散長波式は，波高水深比抄よび相刘水深がともに小

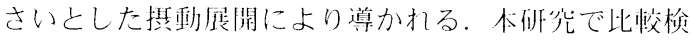

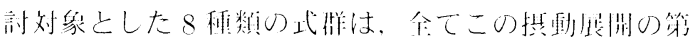

2 次近似の範囲で同一精度である.しかしながら，分散 項と非線形項の大きさが拮抗してくるソリトン分裂現 象では, 分散項の形の違いにより波高や波形の急峻度 が多少異なったものとなる.したがって，津波解析に 適切な非線形分散長波式を採用しなければ，流体力や 陸上遡上高といつた被災のメカ二ズムに関する評価を 正確に行うことができない，そこでまず，水平床の各 非線形分散長波式から, 深海域の津波伝播に重要な線 形分散関係式を導く. 次に, 浅海域の津波伝播に重要 な孤立波に関する解を導き，その波速や波形の急峻度 から各非線形分散長波式の非線形項と分散項の特性を 考察する. 続いて, 非線形性が無視可能な深海域にお ける津波の波数分散現象に関して日本海中部地震津波 を事例として複素フーリ工解析と実用レベルの平面伝 播解析から検討を行う. 最後に, ソリトン分裂現象に 関する水理実駼結果と数值解析結果の比較検討するこ とにより, 津波の数値計算に適切な非線形分散長波式 を検討する。

\section{2. 非線形分散長波式と線形分散特性}

\section{（1）非線形分散長波式}

代表的な非線形分敬長波式としては，断面平均流速 で記述する Peregrine 式, Beji \& Nadaoka 式, Cruz 式 と水深方向に積分して流最フラックス（単位幅流量）で 記述する Mardsen \& Sorensen 式がある。こ机以外に

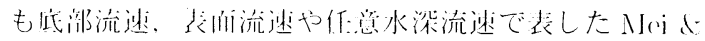


LéM léhaute 式, Dingemans 式 9) Nwogn 式がある. しかしながら, 沚波汁算で重要となる防波堤からの越 流や陸上遡上に対し, 代表点流速で記述された方程式を 使うことは技術的に難しく, 構造物や地形による急激な 水深変化に伴う代表点流速と流量の換算に際し精度が 低下する可能性がある. Kennedy et al. ${ }^{10)}$ は, 遡上域 に細いスリットを仮定することによって，Nwogu タイ プの式で遡上を計算可能にする方法を開発しているが, 数值的取り扱いが煩雑であり, また, 代表点流速から 流量への変換に際し精度が低下する可能性も否定でき ない.いずれにしても，代表点流速を使用した Nwogu タイプの式は, 複雑な陸上遡上や構造物を考慮する必 要がある津波数值計算には不向きであると言える.

本研究において, 検討の対象とした式は, 断面平均 流速あるいは流量フラックス表示の Peregrine 式, Beji \& Nadaoka 式, Cruz 式, Madsen \& Sørensen 式とそ の類似式である. 水平床を仮定して, 具体的に式形を 示すと下記のようになる. すなわち，断面平均表示と しては, 連続式が

$$
\frac{\partial \eta}{\partial t}+\frac{\partial}{\partial x}[(h+\eta) u]=0
$$

運動式は以下の 3 種類の非線形分散長波式である.

$$
\begin{gathered}
\frac{\partial u}{\partial t}+u \frac{\partial u}{\partial x}+g \frac{\partial \eta}{\partial x}=\frac{h^{2}}{3} \frac{\partial^{3} u}{\partial t \partial x^{2}} \\
\frac{\partial u}{\partial t}+u \frac{\partial u}{\partial x}+g \frac{\partial \eta}{\partial x}=-\frac{g h^{2}}{3} \frac{\partial^{3} \eta}{\partial x^{3}} \\
\frac{\partial u}{\partial t}+u \frac{\partial u}{\partial x}+g \frac{\partial \eta}{\partial x}=\frac{2 h^{2}}{5} \frac{\partial^{3} u}{\partial t \partial x^{2}}+\frac{g h^{2}}{15} \frac{\partial^{3} \eta}{\partial x^{3}}
\end{gathered}
$$

断面積分表示としては, 連続式が

$$
\frac{\partial \eta}{\partial t}+\frac{\partial Q}{\partial x}=0
$$

運動式は以下の 5 種類の非線形分散長波式である.

$$
\begin{gathered}
\frac{\partial Q}{\partial t}+\frac{\partial}{\partial x}\left(\frac{Q^{2}}{D}\right)+g D \frac{\partial \eta}{\partial x}=\frac{h^{2}}{3} \frac{\partial^{3} Q}{\partial t \partial x^{2}} \\
\frac{\partial Q}{\partial t}+\frac{\partial}{\partial x}\left(\frac{Q^{2}}{D}\right)+g D \frac{\partial \eta}{\partial x}=\frac{D^{2}}{3} \frac{\partial^{3} Q}{\partial t \partial x^{2}} \\
\frac{\partial Q}{\partial t}+\frac{\partial}{\partial x}\left(\frac{Q^{2}}{D}\right)+g D \frac{\partial \eta}{\partial x}=\frac{\partial}{\partial x}\left[\frac{D^{2}}{3} \frac{\partial^{2} Q}{\partial t \partial x}\right] \\
\frac{\partial Q}{\partial t}+\frac{\partial}{\partial x}\left(\frac{Q^{2}}{D}\right)+g D \frac{\partial \eta}{\partial x}=-\frac{g h^{3}}{3} \frac{\partial^{3} \eta}{\partial x^{3}} \\
\frac{\partial Q}{\partial t}\left(\frac{Q^{2}}{D}\right)+g D \frac{\partial \eta}{\partial x} \\
=\frac{2 h^{2}}{5} \frac{\partial^{3}(2}{\partial t \partial r^{2}}+\frac{g h^{3}}{15} \frac{\partial^{3} \eta}{\partial x^{3}}
\end{gathered}
$$

ここに，uは断而烟流速，Qは流量フラックス(= $u(h+\eta)), \eta$ は水位, $h$ は獬水深, $D$ は全水深 $(=h+\eta)$, $g$ は重力加速度である. な拉, 式 (2) が本来の Peregrine 式, 式 (4) が Beji \& Nadaoka 式と Cruz 式（水平床近似 では同一となる), 式 (10) が Madsen \& Sørensen 式に 該当する．また，式 (6) は，岩瀬ら ${ }^{11)}$ が津波解析に利 用しているものであり, 水深方向に積分した Peregrine 式と名付けてもよい式である. 式 (7) は, 式 (6) の分散 項中の静水深を全水深に置き換えたものである.さら に, 式 (8) は, 有限振幅性を考慮した分散項で, 後藤が 誘導したアーセル数が大きい場合の非線形分散長波式の 簡略式である。.また, 式 (3) および (9) は, Boussinesq によって導かれた式 12) を連続の式と運動の式に分割し, それぞれ断面平均流速および流量フラックスで表記し たものである.

理論方程式の性質を検討するには, 線形分散関係式, 波速, 群速度, 2 次成分波の振幅などを比較する方法が ある.ここでは, 深海域の津波の挙動を再現するため に重要な線形分散特性と, 浅海域のソリトン分裂を再 現するために重要な孤立波解とその波速を各理論方程 式から導き, 比較検討を行う.

\section{（2）線形分散特性}

検討対象とした連続式そして 8 種類の運動式の非線 形項を無視し, 波数分散性を考慮した波速 $c$ を用い, 波 高を $H$, 波数を $k$ として $x$ の正の方向へ伝播する波を $\eta=H \sin k(x-c t)$ とおくと, $\partial / \partial t=-c \partial / \partial x$ そして 連続式から $Q=h u=c \eta$ である. よって, 比較的簡単 に各式の分散関係が求まり, 式 (2), (6), (7), (8) に関 して,

$$
c / c_{0}=\sqrt{1 /\left(1+\sigma_{0} / 3\right)}
$$

式 (3), (9) に関して,

$$
c / c_{0}=\sqrt{1-\sigma_{0} / 3}
$$

そして，式 (4) および (10) に関して,

$$
c / c_{0}=\sqrt{\left(1+\sigma_{0} / 15\right) /\left(1+2 \sigma_{0} / 5\right)}
$$

となる.ここに, $c_{0}(=\sqrt{g h})$ は線形長波の波速であり, また $\sigma_{0}=(k h)^{2}$ である. なお, 式 $(12)$ は $\sigma_{0}>3$ で $c$ が虚数になり, 時間に対して水位の振幅が指数関数的 に増加する解になってしまう. また, 式 (13) は, $\sigma_{0}$ が 大きくなると, $\sqrt{1 / 6}$ に漸近するから, 高周波成分の波 速が $c_{0} / \sqrt{6}$ 以下にならないという性質がある.

各式の波数分散特性の違いを図-1に示す。図には, $\mathrm{KdV}$ 式

$$
\frac{\partial \eta}{\partial t}+c_{0} \frac{\partial \eta}{\partial x}+c_{0} \frac{3 \eta}{2 h} \frac{\partial \eta}{\partial x}+c_{0} \frac{h^{2}}{6} \frac{\partial^{3} \eta}{\partial x^{3}}=0
$$




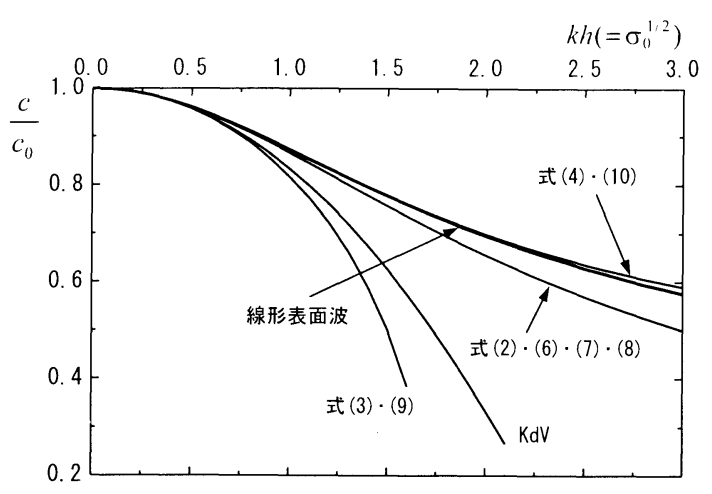

図-1 線形分散関係

の分散関係式

$$
c / c_{0}=1-\sigma_{0} / 6
$$

および線形表面波の分散関係式

$$
c / c_{0}=\sqrt{\sigma_{0}^{-1 / 2} \tanh \sigma_{0}^{1 / 2}}
$$

も示している.

式 (3), (9) は, $k h=0.6$ 以上で線形表面波の差は $1 \%$ を越え分散効果が過大となる。また, 式 (2), (6), (7), (8) の分散関係は， $k h=1.0$ 程度までであれば線 形表面波と差は $1 \%$ に満たない. しかし， $k h=1.0$ を 越えると線形表面波の分散関係から外れ高周波成分の 波速が遅くなり，分散効果が線形表面波に比べ相対的 に大きく評価されている，一方，線形分散に適合する ように改善された式 (4)，(10) は, 線形表面波の分散効 果に比べ過小評価となる傾向にあるが, $k h=2.4$ 程度 までは線形表面波の差は $1 \%$ 末満となり良好な分散関 係がみられる.よって, 線形分散特性から判断すると, 式 (4), (10) が優れていると言える. また, 式 (3), (9) は, $\sigma_{0}>3$ で永年項が発生するため, 高波数成分が卓 越する場合, 安定した解が得られない可能性があり, 津 波の数值計算への適用には問題がある.

\section{3. 孤立波の第 1 次近似解}

\section{(1) 解法}

遠浅な浅海域を伝播する津波は，ときによってソリ トン分裂を起こす場合がある.ソリトン分裂波の挙動 は，支配方程式における非線形効果と波数分散效果の 相対的なバランスが重要な役割となる。ここでは, 各 支配方程式に扮ける 1 次近似の孤立波解老導き，非線

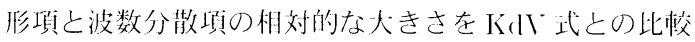
加娭部在行う。
Peregrine 式など断面平均流速で䛉述されている非線 形分散長波式は, 全水深 $D$ をかけると下記のように流 量フラックス表示の式へ書き換えることができる。

$$
\begin{aligned}
D\left[\frac{\partial u}{\partial t}\right. & \left.+u \frac{\partial u}{\partial x}+g \frac{\partial \eta}{\partial x}\right] \\
& =\frac{\partial Q}{\partial t}+\frac{\partial}{\partial x}\left(\frac{Q^{2}}{D}\right)+g D \frac{\partial \eta}{\partial x}
\end{aligned}
$$

したがって，式 (2)，(3)，(4) は，それぞれ

$$
\begin{aligned}
\frac{\partial Q}{\partial t}+\frac{\partial}{\partial x}\left(\frac{Q^{2}}{D}\right) & +g D \frac{\partial \eta}{\partial x} \\
& =D\left[\frac{h^{2}}{3} \frac{\partial^{3}}{\partial t \partial x^{2}}\left(\frac{Q}{D}\right)\right]
\end{aligned}
$$

$$
\frac{\partial Q}{\partial t}+\frac{\partial}{\partial x}\left(\frac{Q^{2}}{D}\right)+g D \frac{\partial \eta}{\partial x}=D\left[-\frac{g h^{2}}{3} \frac{\partial^{3} \eta}{\partial x^{3}}\right]
$$

$$
\begin{aligned}
\frac{\partial Q}{\partial t} & +\frac{\partial}{\partial x}\left(\frac{Q^{2}}{D}\right)+g D \frac{\partial \eta}{\partial x} \\
& =D\left[\frac{2 h^{2}}{5} \frac{\partial^{3}}{\partial t \partial x^{2}}\left(\frac{Q}{D}\right)+\frac{g h^{2}}{15} \frac{\partial^{3} \eta}{\partial x^{3}}\right]
\end{aligned}
$$

と変形できる. 以上のことから，検討対象とする 8 種 類の運動式の局所項, 移流項 (非線形項), 静水圧力項 は同一形となり，違いは分散項に限定され，本研究にお いては, この断面積分形の式を利用した解析を行う.

いま, 一例として最も簡単と思われる連続式 (5) と 運動式 (6) からなる非線形分散長波式に関する孤立波 の第 1 次近似解を導く. 孤立波の波形として

$$
\eta=H \operatorname{sech}^{2} k(x-c t)
$$

を仮定すると, 線形分散関係式の導出の場合と同様に $\partial / \partial t=-c \partial / \partial x$ と連続式から $Q=c \eta$ が成り立つこと がわかる. ここで, $\epsilon=\eta / h, \epsilon_{0}=H / h, \sigma_{0}=(k h)^{2}$ と おくと,

$$
\begin{gathered}
\frac{\partial Q}{\partial t}=-c^{2} \frac{\partial \eta}{\partial x} \\
g D \frac{\partial \eta}{\partial x}=c_{0}^{2}(1+\epsilon) \frac{\partial \eta}{\partial x}
\end{gathered}
$$

$$
\frac{\partial}{\partial x}\left(\frac{Q^{2}}{D}\right)=c^{2}\left[2 \epsilon+O\left(\epsilon_{0}^{2}\right)\right] \frac{\partial \eta}{\partial x}
$$

$$
h^{2} \frac{\partial^{3} Q}{\partial t \partial x^{2}}=-c^{2} \sigma_{0}\left(4-12 \frac{\epsilon}{\epsilon_{0}}\right) \frac{\partial \eta}{\partial x}
$$

となる。故に，非線形分散長波式 (6) は,

$$
\begin{aligned}
& {\left[-c^{2}+c_{0}^{2}(1+\epsilon)+c^{2}(2 \epsilon)\right.} \\
& \left.\quad+\iota^{2} \frac{\sigma_{0}}{3}\left(4-12 \frac{\epsilon}{\epsilon_{0}}\right)\right] \frac{\partial_{I I}}{\partial x}+O\left(\epsilon_{0}^{\circ}\right)=0(26)
\end{aligned}
$$


表-1 抓汒波解の比較

\begin{tabular}{c|l|l|l}
\hline Equation & Dispersive Term & Relative Depth & Celerity \\
\hline KdV & $\frac{c_{0} h^{2}}{6} \frac{\partial^{3} \eta}{\partial x^{3}}$ & $\sigma_{0}=\frac{3 \epsilon_{0}}{4}$ & $\frac{c}{c_{0}}=1+\frac{2 \sigma_{0}}{3}$ \\
\hline Eq.(6) & $\frac{h^{3}}{3} \frac{\partial^{3} Q}{\partial t \partial x^{2}}$ & $\sigma_{0}=\frac{3 \epsilon_{0}}{4}\left(1+\frac{\epsilon_{0}}{3}\right)^{-1}$ & $\frac{c}{c_{0}}=\frac{1}{\sqrt{1-4 \sigma_{0} / 3}}$ \\
\hline Eq.(7) & $\frac{D^{2}}{3} \frac{\partial^{3} Q}{\partial t \partial x^{2}}$ & $\sigma_{0}=\frac{3 \epsilon_{0}}{4}\left(1+\frac{5 \epsilon_{0}}{3}\right)^{-1}$ & $\frac{c}{c_{0}}=\frac{1}{\sqrt{1-4 \sigma_{0} / 3}}$ \\
\hline Eq.(8) & $\frac{\partial}{\partial x}\left[\frac{D^{3}}{3} \frac{\partial^{2} Q}{\partial t \partial x}\right]$ & $\sigma_{0}=\frac{3 \epsilon_{0}}{4}\left(1+2 \epsilon_{0}\right)^{-1}$ & $\frac{c}{c_{0}}=\frac{1}{\sqrt{1-4 \sigma_{0} / 3}}$ \\
\hline Eq.(2) & $D\left[\frac{h^{2}}{3} \frac{\partial^{3}}{\partial t \partial x^{2}}\left(\frac{Q}{D}\right)\right]$ & $\sigma_{0}=\frac{3 \epsilon_{0}}{4}\left(1-\frac{\epsilon_{0}}{3}\right)^{-1}$ & $\frac{c}{c_{0}}=\frac{1}{\sqrt{1-4 \sigma_{0} / 3}}$ \\
\hline Eq.(9) & $\frac{g h^{3}}{3} \frac{\partial^{3} \eta}{\partial x^{3}}$ & $\sigma_{0}=\frac{3 \epsilon_{0}}{4}\left(1-\frac{2 \epsilon_{0}}{3}\right)^{-1}$ & $\frac{c}{c_{0}}=1+\frac{3 \sigma_{0}}{4}$ \\
\hline Eq.(3) & $D\left[\frac{g h^{2}}{3} \frac{\partial^{3} \eta}{\partial x^{3}}\right]$ & $\sigma_{0}=\frac{3 \epsilon_{0}}{4}$ & $\frac{c}{c_{0}}=1+\frac{3 \sigma_{0}}{4}$ \\
\hline Eq.(4) & $\frac{2 h^{2}}{5} \frac{\partial^{3} Q}{\partial t \partial x^{2}}+\frac{g h^{3}}{15} \frac{\partial^{3} \eta}{\partial^{3} x}$ & $\sigma_{0}=\frac{3 \epsilon_{0}}{4}\left(1+\frac{8 \epsilon_{0}}{15}\right)^{-1}$ & $\frac{c}{c_{0}}=\frac{\sqrt{1-4 \sigma_{0} / 15}}{\sqrt{1-8 \sigma_{0} / 5}}$ \\
\hline
\end{tabular}

と変形できる. したがって, 定常的な孤立波の解が存 在するためには, $O\left(\epsilon_{0}\right)$ の範囲で

$$
\begin{aligned}
-1+\left(c_{0} / c\right)^{2}(1 & +\epsilon)+2 \epsilon \\
& +\left(\sigma_{0} / 3\right)\left(4-12 \epsilon / \epsilon_{0}\right)=0
\end{aligned}
$$

すなわち，

$$
-1+\left(c_{0} / c\right)^{2}+4 \sigma_{0} / 3=0
$$

および

$$
\left(c_{0} / c\right)^{2}+2-4 \sigma_{0} / \epsilon_{0}=0
$$

が恒等的に成立する必要がある，故に，

$$
c / c_{0}=1 / \sqrt{1-4 \sigma_{0} / 3}
$$

および

$$
\sigma_{0}=\left(3 \epsilon_{0} / 4\right)\left(1+\epsilon_{0} / 3\right)^{-1}
$$

であり, 波高水深比 $\epsilon_{0}$ が与えられれば，対応する孤立 波の波形が定まったことになる，なお，式 (18)，(20) は, 分散項の取り扱いが多少複雑となるが,

$$
h^{2} \frac{\partial^{3}}{\partial t \partial x^{2}}\left(\frac{Q}{D}\right)=-c^{2}\left[h(1+\epsilon)^{-2} \frac{\partial^{3} \eta}{\partial x^{3}}\right]+O\left(\epsilon_{0}^{2}\right)
$$

であることに留意すると上:述の片で泒立波の第 1 次 近似解在求めることができる.

\section{（2）孤立波の解の比較}

運動式 (6) 以外の 7 種類の運動式に関して, 上述と 同様な解析により $O\left(\epsilon_{0}\right)$ の範囲でそれぞれの孤立波の 第 1 次近似解を導き, 相対水深と波速比の違いとして 整理したものが表-1である，仮定した孤立波の解は，

$$
\begin{aligned}
\eta & =H \operatorname{sech}^{2} k(x-c t) \\
& =H \operatorname{sech}^{2}\left(\sigma_{0}^{1 / 2} h^{-1}\right)(x-c t)
\end{aligned}
$$

であるので， $\sigma_{0}$ が小さいほど幅広の孤立波形であり, 大きいほど急峻な孤立波形であることを意味する，し たがって, KdV 式に比べ, 式 (6), (7)，(8)，(10)の孤 立波の解が幅広であり, 式 (2), (4), (9) が急峻となる. 特に, 断面平均表示の式 (2) を利用した数值解析におい て, 既往の研究 ${ }^{11), 13)}$ により算出される波高が過大に なりすぎることが指摘されており，このことは導出し た孤立波の解の形とも符合する。な押，孤立波の波形 は, 分散項と非線形項の相対的な大きさを表している と考えることができる.すなおち, 非線形項は波形を 前傾化すなわち急峻にする方向に作用し, 分散項は幅 広の方向になるように作用する。したがって, 急峻な 解は, 非線形項に比べ分散項が相対的に小さいことを 意味し, 逆に幅広の解は非線形項に比べ分散項が相対 似に大きいことになる。

また，K小式の解には保存則が成立することが州ら 

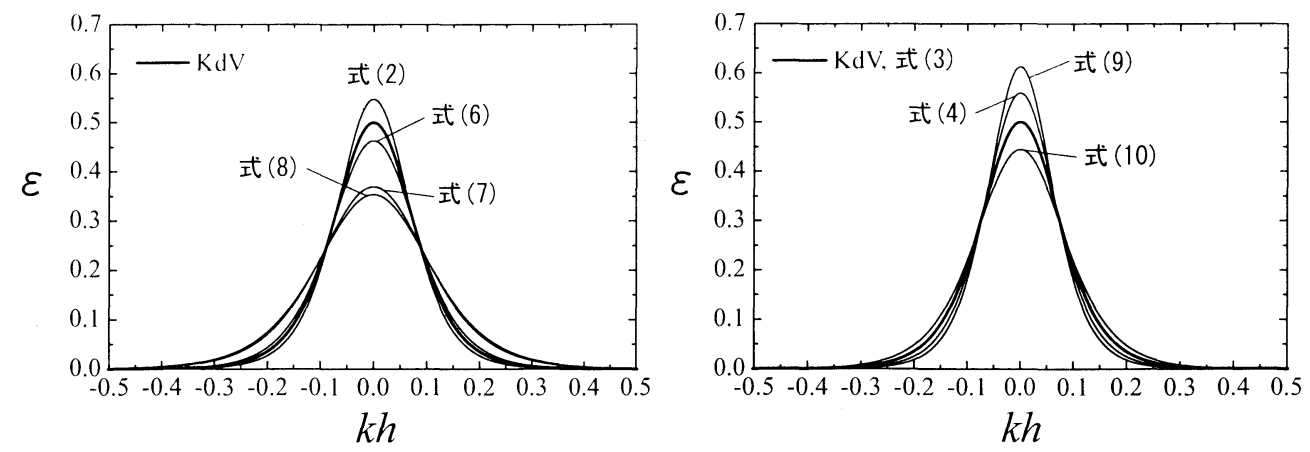

図-2 孤立波形の比較

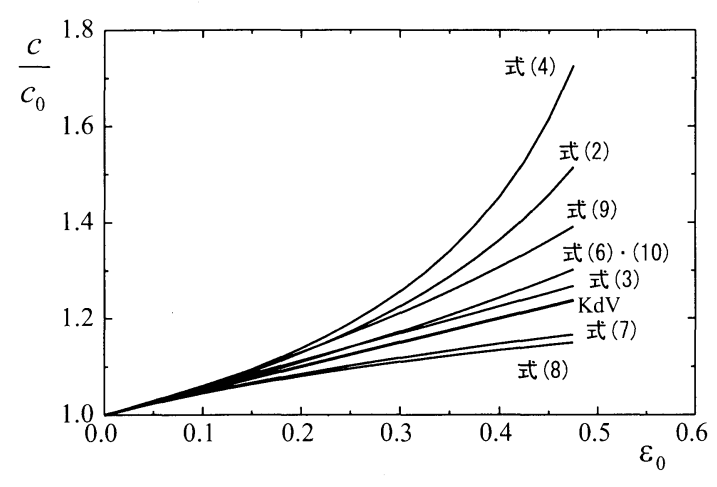

図-3 孤立波の波速に関する比較

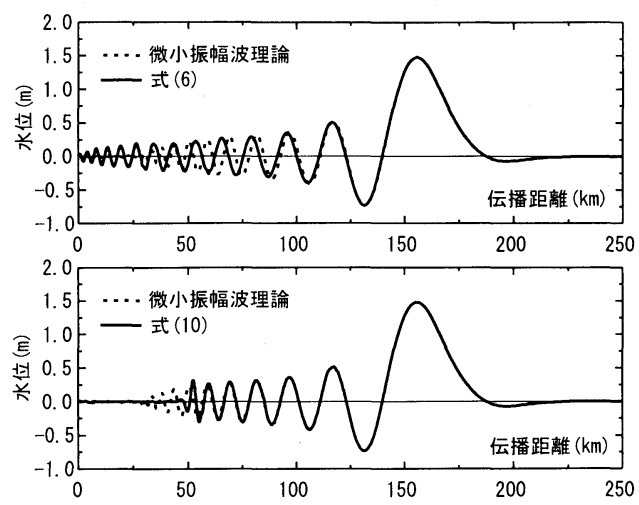

図-4 深海域における津波の伝播特性

(2)，(4) そして (9) は過大評価, 式 (7), (8) は過小評価 であると考えられる. 故に, 式 (3), (6) そして (10) を 用いることが望ましいと言える.

\section{4. 数値解析による深海域の津波伝播}

\section{（1）フーリエ変換による数值解析}

線形分散特性の比較検討により, 津波解析には深海 域では式 (4)，(10) が適していることを示した。一般に, 近地津波では波数分散効果が無視できるものと仮定し ているが, 近地津波であっても深海域の分散性が無視で きない津波が存在するこを著者らは示している ${ }^{16)}$ 。特 に深海域では非線形性が無視できるため線形分散性に よってのみ伝播変形の精度が決定される. そこで, 深海 域の津波の伝播に関して式 (6)（=式 (2), (7), (8)）と 式 (10)（=式 (4)）の比較を行う. 式 (9)（=式 (3)）は, 線形分散特性の精度が劣り, かつ $k h=\sqrt{3}$ 以上で発散 するため除外した. 対象とする初期波形は, 相田 ${ }^{17)} に$ より推定された日本海中部地震津波の指向性の最も大 きい方向に関する断面波形であり, 非線形分散長波式 の水深 $3000 \mathrm{~m}$ の一定水深を 15 分閣, 約 $150 \mathrm{~km}$ 伝播さ せた場合の空䦌波形の比洨在行う。な㧍, 波形》は高 
速フーリエ変換により初期波形を複素フーリエ係数 $A_{n}$ に分解し，

$$
\eta=\sum_{n=0}^{N-1} \frac{1}{2} A_{n}\left[e^{i k_{n}\left(x-c_{n} t\right)}+e^{i k_{n}\left(x+c_{n} t\right)}\right]
$$

と計算している. ここに, $k_{n}$ は $n$ 番目のフーリエモー ドに対応する波数, そして $c_{n}$ は各式のフーリエモード に対応する波速である.

図-4は，初期波形に対する各線形分散関係を考慮し た高速フーリ工変換から得られた空間波形である. 図 から判断できるように, 式 (6) および (10) による計算 值は, ともに比較的良好に線形表面波から算定した主 峰と分散波列を近似している. 特に, 式 (10) を利用し た計算值の精度が良い. ただし, 式 (13) から明らかな ように $k h$ すなわち $\sigma_{0}$ が大きくなると線形表面波の分 散関係から徐々に離れ, $c / c_{0}=\sqrt{1 / 6}=0.408$ に漸近 するという特性がある. 通常の波浪のような水深が比 較的浅く連続的な波を解析する場合には, このことを さほど重要視する必要がないと思われるが, 深海域の 津波のような一山一谷の波の伝播現象を取り扱う際に は, ある程度以上の高波数成分がほぼ同一の伝播速度 で進むため, 図-4 下の $x=60 \mathrm{~km}$ 付近で見られるよう な分散波列の終端部にエネルギーの一部が集積して生 成される終端波が生じる. 浅海域においては, 非線形 性によりさらに高周波成分が生成されるため, 場合に よっては, このことが大きな問題となる可能性がある.

\section{(2) 差分式による数値解析}

そこで, 式 (6) および(10) を 2 次元に抎張した支配 方程式を用い, 日本海中部地震津波を対象とした平面 伝播計算から終端波の検討を行う. 差分法における計 算スキームとしては混合差分法 ${ }^{10)}$ を用いる. 差分式の 一例として, 連続式 (5) と運動式 (6) に関するものを下 記に示す. 混合差分法は, 陽的に取り扱う 1 段目の計 算と陰的な 2 段目の計算に分けられ，1段目の連続式の 計算が,

$$
\frac{1}{\Delta t}\left[\eta_{j}^{n+1 / 2}-\eta_{j}^{n-1 / 2}\right]+\frac{1}{\Delta x}\left[Q_{j+1 / 2}^{n}-Q_{j-1 / 2}^{n}\right]=0
$$

運動式の計算が

$$
\frac{1}{\Delta t}\left[Q_{j+1 / 2}^{*}-Q_{j+1 / 2}^{n}\right]+\frac{g D}{\Delta x}\left[\eta_{j+1}^{n+1 / 2}-\eta_{j}^{n+1 / 2}\right]=0
$$

で表される. 2 段目は運動式の移流項および分散項に関 する計算であり,

$$
\frac{1}{\Delta t}\left[Q_{j+1 / 2}^{n+1}-Q_{j+1 / 2}^{*}\right]
$$

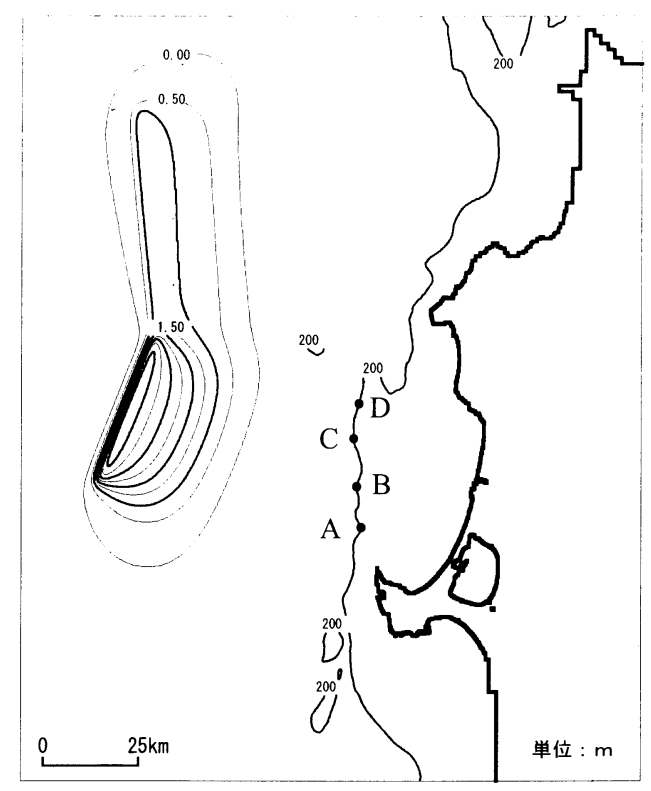

図-5 1983 年日本海中部地震津波初期分布と $200 \mathrm{~m}$ 等深線

$$
\begin{aligned}
& +\frac{1}{4 \Delta x}\left[\left(\frac{Q}{D}\right)_{j+3 / 2}^{n} Q_{j+3 / 2}^{n+1}-\left(\frac{Q}{D}\right)_{j-1 / 2}^{n} Q_{j-1 / 2}^{n+1}\right] \\
& +\frac{1}{4 \Delta x}\left[\left(\frac{Q}{D}\right)_{j+3 / 2}^{n} Q_{j+3 / 2}^{n}-\left(\frac{Q}{D}\right)_{j-1 / 2}^{n} Q_{j-1 / 2}^{n}\right] \\
& =\frac{h^{2}}{3 \Delta t \Delta x^{2}}\left[Q_{j+3 / 2}^{n+1}-2 Q_{j+1 / 2}^{n+1}+Q_{j-1 / 2}^{n+1}\right] \\
& -\frac{h^{2}}{3 \Delta t \Delta x^{2}}\left[Q_{j+3 / 2}^{n}-2 Q_{j+1 / 2}^{n}+Q_{j-1 / 2}^{n}\right]
\end{aligned}
$$

となる.ここに, $j, n$ は差分格子番号を表し，時間そし て空間の差分格子間隔を $\Delta t, \Delta x$ とおくと時間および空 間座標がそれぞれ $t=n \Delta t, x=j \Delta x$ で表される. 差 分式を見ると明らかなように混合差分スキームは，分 散項を含め全ての項が時空間に対して対称な差分形と なっている. また, 移流項に関しては, 時空間に中央差 分として計算する形式となっている，このように，各 種非線形分散長波式の比較に混合差分法を用いた理由 としては, 打ち切り誤差（数值分散）が ADI 法などの ほかのスキームに比べ小さしとによる.なお, 混合 差分法の打ち切り誤差特性の詳細に関しては別の機会 に報告する．

図-5 は津波初期波形分布と $200 \mathrm{~m}$ 深等深線を描いた ものである，空間格子は実用的なレベルを考虑し，空 間格子を $\Delta x=\Delta y=400 \mathrm{~m}$ の正方格子, 時間ステップ を $\Delta t=0.2 \mathrm{~s}$ とする. 図-6 は, 図-5 に示す $200 \mathrm{~m}$ 代表 水深点 $(\mathrm{A} \sim \mathrm{D})$ における水位経時変化を示したもので ある、線形分散特性と同様, 式 (6) の結果は式 (10) に 比べ分散波列の位相が後退するものの, 第 1 波, 第 2 

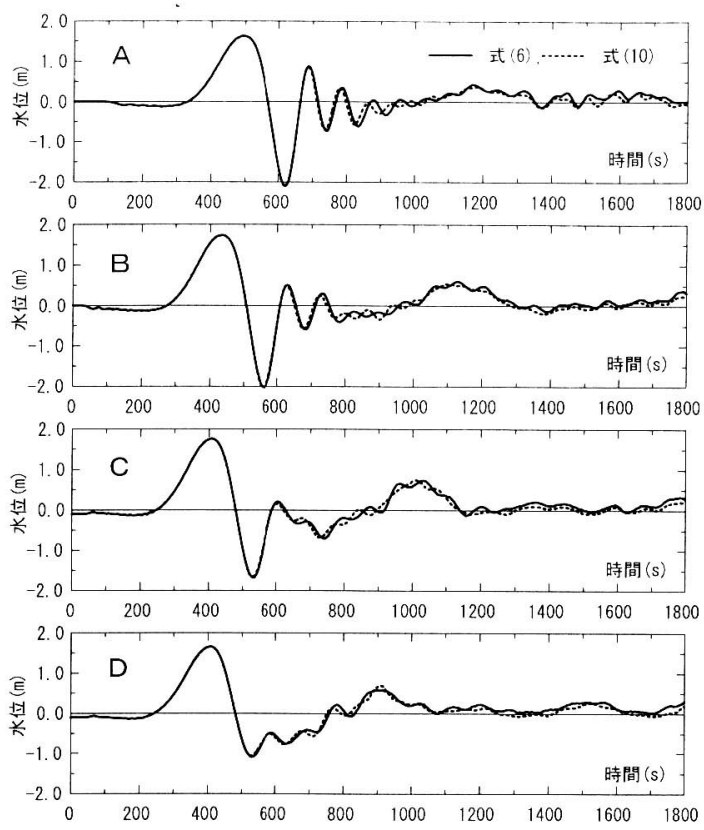

図-6 $200 \mathrm{~m}$ 水深地点の水位経時変化

波には大きな差異は見られず，終端波の影響も確認で きない，また，図-7は，10 分後の津波波形を示したも のである．水位比較と同様，この図からも同様に終端 波の影響怡確認できない，平面伝播では，軍動の水平 方向への広がりに加え，海底地形による反射・屈折お よび数值分散性の影響から高周波成が分抑えられたこ ともあり，今回設定した空間格子の大きさ $(400 \mathrm{~m})$ で は，式(10)を津波数值計算に適応することに問題はな いと言える。一方, 線形分散特性は, 式 (10)の方が式 (6)より優扎ているが，図-6の結果からは式 (6) と式 (10)の間に顕著な差が見ら扎ない。したがって，遠地 津波の場合や，近地津波でも細かな格子を使った詳細 な計算を行う場合には，式 (10) の優位性が期待できる ものの，近地津波に対して，現時点で䒠際に使用され ている程度の格子間隔を用いる場合，雨者の差はそれ ぼど大きくないと言える。

\section{5. 数值解析による浅海域の津波伝播}

\section{（1）ソリトン分裂としての数值解析}

ここでは，浅海域在伝播する津波在刘象とし，水理尖 験之差分法による数值解析の比洨在通じて, 非線形效 果と分散効果の相互干渉で起こるリリトン分裂現象に 関する非線形分散厓波式の特性について考察する。対象 とする支酒方程式は，式(2)，(6)，(8) 抄上び(10)であ

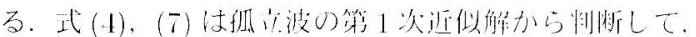

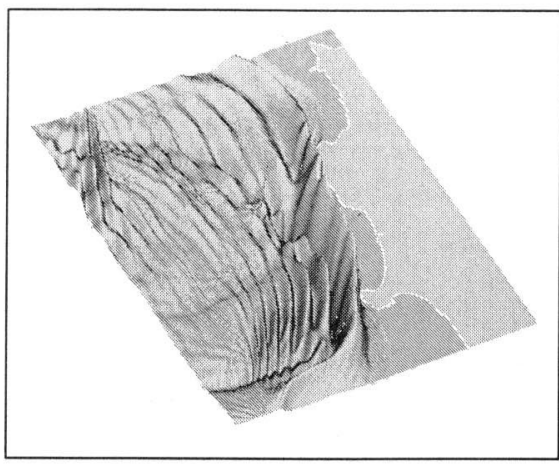

式(6)による計算結果

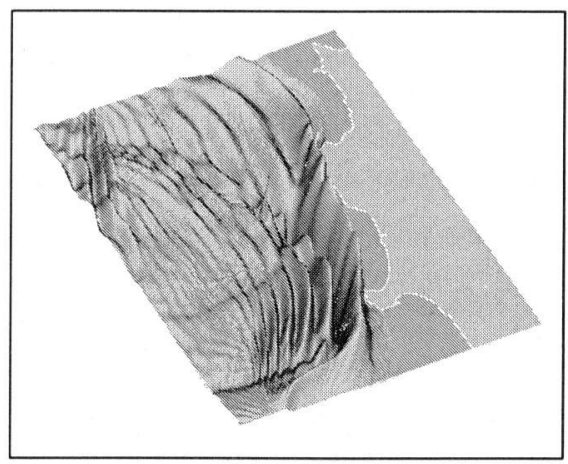

式(10)による計算結果

図-7 10 分後の津波波形

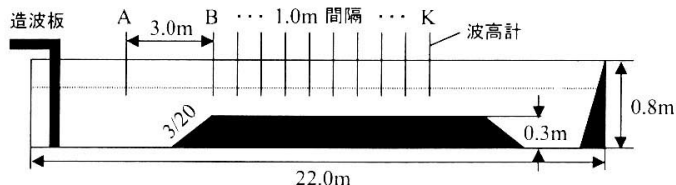

図-8 実験装置

それぞれ式 (2) および (8) と同様な特性があることがお かっているため割愛した。また，式 (3) 抢よび (9) は， 線形分散特性が劣り深海域から浅海域までの逨続的な 津波解析に不向きであることから除外した。平面解析 同様，差分スキ一ムは 2 段階混分差分法を利州する。

\section{（2）水理実験}

水理実験には，図-8 に示寸東游大学丁学部十木厂学 科所有の全长 $22 \mathrm{~m}$, 慓 $0.5 n$, 高さ 0.811 の雨侕ガラス 張りの造波水慒を使用した。造波㙨はバソコン制御型 のヒストン性タイブである。水戍顺状は，波斨の前 倾化在促寸ための公限 $3 / 20$ の斜洏部とりリトン分裂の

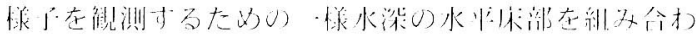



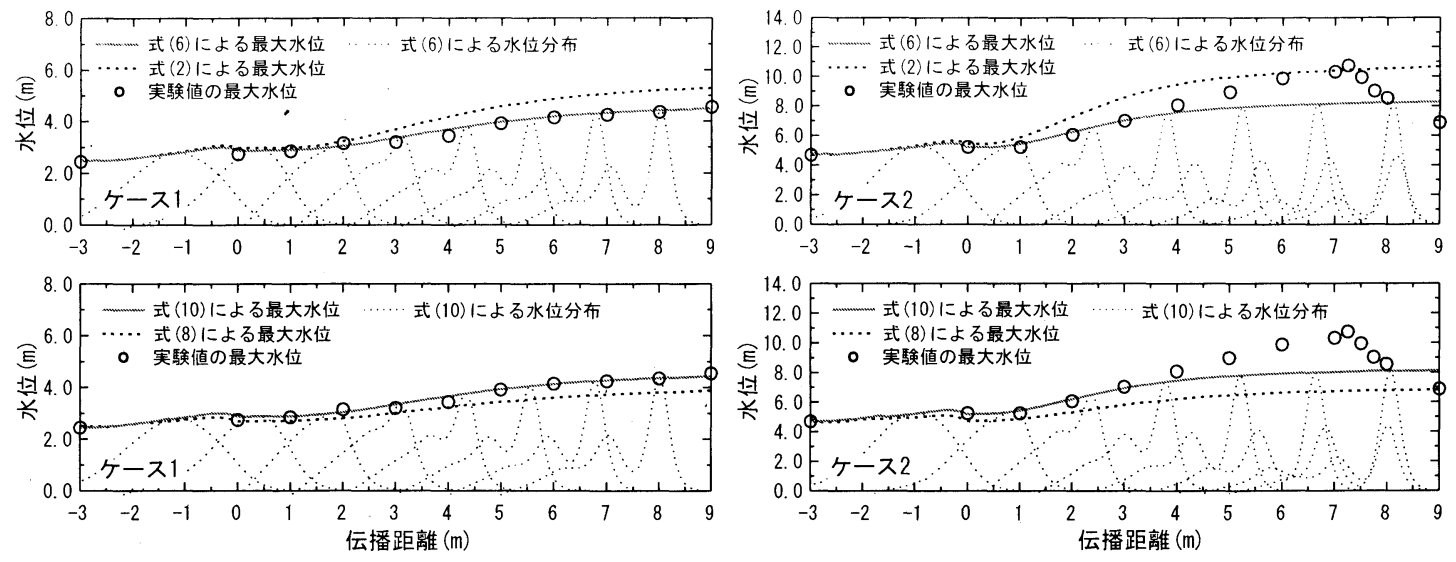

図-9 空間水位分布の比較

せたものである．ただし，実験装置の全長が $22 \mathrm{~m}$ と短 いため, 定常波形としての孤立波に関する観測が困難 であり, 比較検討はソリトン分裂の変形過程の一部に 制限される. また, 検討する支配方程式群は, 水平床を 仮定したものであるため分散項中の水深勾配項は考慮 されていない. 水理実験装置には勾配 $3 / 20$ の斜面部を 有するが, 式 (6) の計算値と, 式 (6) で水深勾配を考慮 した式の計算值（波高計 B の位置）との比較から，水 位に大きな差が見られなかったことから, 本実験装置 程度の水深変化によるソリトン分裂への影響は小さい ものと判断した.

数值解析と比較する実験ケースは, 計測範囲で砕波 が起こらない事例（実験ケース 1）と砕波が起こる事例 （実験ケース 2）の 2 種類である.すなおち, 実験ケー 又 1 は, 上部水深（水平床部水深）が $0.106 \mathrm{~m}, \mathrm{~A}$ 点の 波高が $0.024 \mathrm{~m}$, 水平床部の波高水深比の変化が 0.26 か ら 0.45 であり, 実験ケース 2 は, 上部水深（水平床部 水深）が $0.12 \mathrm{~m}, \mathrm{~A}$ 点の波高が $0.047 \mathrm{~m}$, 水平床部の波 高水深比の変化が 0.44 から 0.86 である. なお, 計測に は, 図中の A から K の記号で示す 11 本の容量式波高 計を利用している.ただし, 図に示しているのは, 実 験ケース 1 に関する波高計の配置であり, 実験ケース 2 に関しては砕波位置を考慮して波高計の位置を変えて いる. なお，便宜上水平床開始する点（波高計 B）を 伝播距離の原点とする.

\section{(3) 実験值との比較}

波高計A点で観測された水位時系列デー夕を境界值 とし, 式 (2)，(6)，(8) および (10)の運動式を用いて $\Delta t=0.005 \mathrm{~s}, \Delta x=0.02 \mathrm{~m}$ (クーラン数は 2 ケースともに 約 0.5$)$ として行った計算值と実験傎を比較したものを 図-9 挍ひひ図-10 に示す。
図-9 は，それぞれ実験ケース 1（左図）および実験 ケース 2（右図）に関する水位の空間分布および最大水 位分布であり, 白丸が実験值の最大水位, 破線および 実線が各方程式による計算值の最大水位，そして細破 線が $1 \mathrm{~s}$ 毎の運動式 (6) および (10) の空間水位である. なお，図の横軸は，波高計設置位置の $\mathrm{A}$ 点を基準とす る距離である. 砕波が起こらない比較的波高水深比が 小さな実験ケース 1（図-9 左）では, 孤立波の第 1 次 近似解の急峻度特性から推定できるように，ソリトン 分裂が始まると式 (2) の計算結果は, 増幅率が過大評価 となり実験值に比べ波高が高く, 式 (8) の計算結果は, 増幅率が過小評価となり実験值に比べ波高が低くなる. 一方，式 (6) および (10) の計算結果は，実験值とかな りの精度で実験值と一致する. 砕波が起こる比較的波 高水深比が大きな実験ケース 2（図-9 右）でも, 各式 による計算結果による波高増幅の傾向は同じである. 特 に，式 (6) および (10) の計算結果は，両図から判断で きるように, 波高水深比 0.65 程度までは実験值と良く 一致する. しかし, 波高水深比が 0.65 以上となる範囲 では増幅率が過小評価となり，実験值との差異が見ら れる。

図-10 は, 計算值と実験值の水位水位の経時変化を 表したものであり, 図左は実験ケース 1 の $6.00 \mathrm{~m}$ 地点, 右図は実験ケース 2 の $7.25 \mathrm{~m}$ 地点 (䂥波点)のものであ る. 波高水深比が小さい実験ケース 1 の場合には，波 形の形状を含めた式 (6) と (10) の計算值の精度が高い ことが分かる. 式 (2) は波高が過大評価で波速も速すぎ る. 式(8) は波高が過小評価で波速も遅すぎる結果を 与えている. 式 (6) と (10) の結果を比べると, 波高に 関してはほとんど差が無く, 位相に関しては僅かに式 (6)の方が実騟值に近い結果を与えている．また，実験 ケース 2 の場合, 式 $(6)$ と (10) は, 訛波直前の急激な 

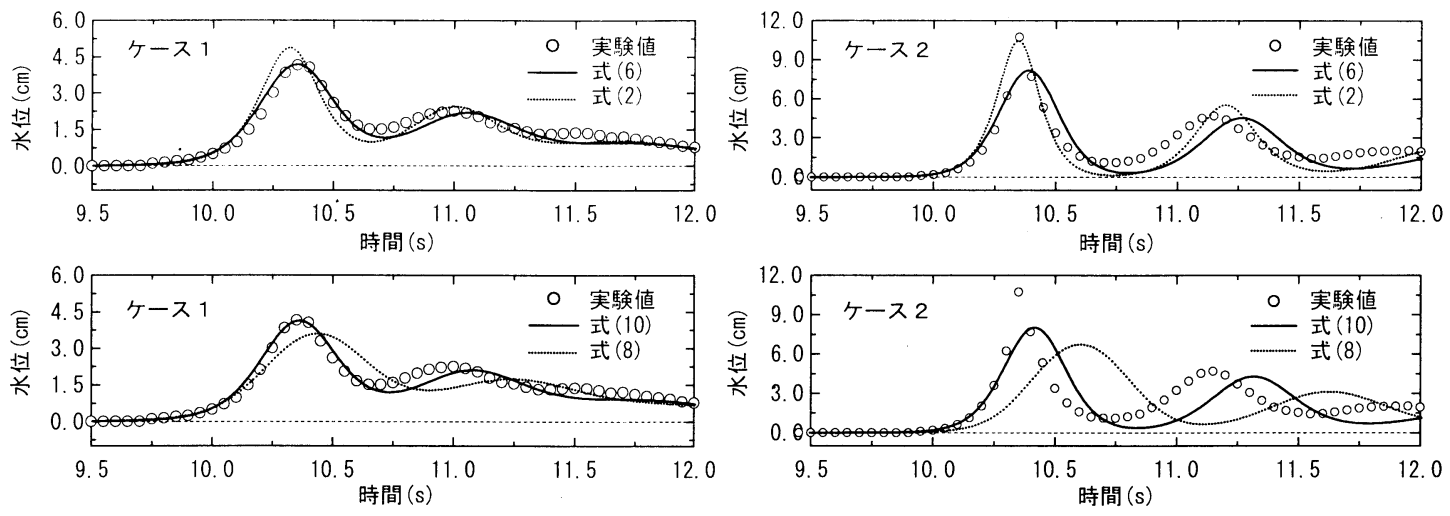

図-10 水位経時変化の比較（ケース 1:6.00m 地点, ケース $2: 7.25 \mathrm{~m}$ 地点）

波高の増幅効果を再現できない。これは，岩瀬らによ る研究 ${ }^{18)}$ から, 鉛直積分型の非線形分散長波式の限界 であると考えられる. なお，図-10右上の図で，式 (2) の第 1 波波高が実験值と一致しているが, 式 (2) は増 幅率が過大評価のため，たまたま砕波波高と一致した ものと考えられる.

以上のように, 実験值と計算值の比較から, 砕波点近 傍における波高増幅が過小評価になるものの, 浅海域 のソリトン分裂については式 (6) および式 (10) が優れ ていることが分かる. 式 (6) と (10) の結果に大きな差 はないが, ソリトン分裂波の位相まで考慮すると, 僅か ながら式 (6) の方が式 (10) に比べて優れている.ただ し, 第 2 波目以降の分裂波形および砕波直前の急激な 波高増幅に伴う実験値と計算值の差異に関しては, 何 らかの修正モデルを検討して行く必要があり, 今後水 理実験との詳細な比較を通じて検討を行う予定である.

\section{6. おわりに}

非線形分散長波式は, $O\left(\epsilon_{0}\right)=O\left(\sigma_{0}\right) \ll 1$, すなわ ちア一セル数 $U_{r}=\epsilon_{0} / \sigma_{0}$ が $O(1)$ と仮定して捸動展開 を利用して導かれる。摂動展開の 2 次近似では, 検討 対象とした 8 種類の運動式はすべて同じオーダーであ る.しかしながら, その孤立波の第 1 次近似解は大き く異なる. 津波の伝播・変形を対象とする場合には深海 域では線形分散特性が，また，浅海域のソリトン分裂 では非線形性と分散性の相対的大きさを意味する孤立 波の第 1 次近似解の急峻度が特に重要である。これら 理論的な考察および水理実験を含む数值解析との比較 から, 深海域では式 (10) が優狆ている。ただし, 近地 津波で実用的な大きさの格子を使っている範国では式 (6) とそればどの差はない。浅海域のソリトン分裂とし ては，武 (6)，(10)がほぼ闹程度だが，式 (6)のうが倬 かに優㧈ている。したがって, 深游域から浅游域まで
の連続的な津波計算として, 式 (6), (10) は他の支配方 程式に比べ優れており, 式 (6), (10) にはそれほど大き な差はないと言える。

謝辞： 本研究をまとめるにあたり東海大学工学部土 木工学科水工研究室の学部生および大学院生諸君の助 力を得た. また, 本研究は, 文部科学省科学研究費 (基 盤研究 (B)(1) 代表 : 入江 功九州大学教授, 基盤研究 (C) (2) 代表 : 後藤智明) を利用して実施した.ここに 記して謝意を表す。

\section{参考文献}

1) Korteweg, D.J. and DeVries, G. : On the change of form of long waves advancing in a rectangular canal and on a new type of long stationary waves, Phil. S5, Vol.39, No.240, pp.422-443, 1895.

2) Mei, C.C. and LéMéhaute, B. : Note on a equations of long waves over an uneven bottom, J. Geophs. Res., Vol.71, pp.393-400, 1966.

3) Peregrine, D.H. : Long waves on a beach, J.F.M., Vol.27, Part 4, pp.815-827, 1967.

4) 後藤智明: アーセル数が大きい場合の非線形分散波の 方程式, 土木学会論文集, 第 351 号/ II -2, pp.193-201, 1984.

5) Madsen, P.A. and Sørensen O.R. : A new form of the Boussinesq equations with improved linear dispersion characteristics, Part 2, A slowly-varying bathymetry, Coastal Eng., Vol.18, pp.183-204, 1992.

6) Nwogu, O.: An alternative form of the Boussinesq equations for nearshore wave propagation, J. Waterway, Port, Coastal and Ocean Eng., Vol.119, No.6, pp.618-638, 1993

7) Beji, S. and Nadaoka, K.: A formal derivation and numerical Modelling of the imporoved Boussinesq equations for varying depth, Ocean Eng., Vol.23, pp.691704, 1996

8）Cruz, E.C., 石倉正英, 青野利夫 : 非線形分散モデルを 用いた開境界処理に関する研究, 土木学会, 海岸工学論 文集, Vol.44, No.1, pp.46-50, 1987.

9) Dingemans, M. W. : Water waves over an uneven bottom - A discussion of long-wave equations, Rep. R 729- II. Delft Hydr. Lab., Delft, The Netherlands, 1973. 
10) Kennedy, A. B., Chen, Q., Kirby, .J. T. and Dalrymple, R. A. : Boussinesq modelling of wave transformation, breaking, and runup. I : 1D., J. Wtrwy., Port, Coast., and Oc. Engrg., ASCE, Vol. 126, No. 1, pp.39$47,2000$.

11) 岩瀬浩之, 見上敏文, 後藤智明: 非線形分散波理論を用い た実用的な津波計算モデル，土木学会論文集，No.600/ II -44 , pp.119-124, 1998.

12) Boussinesq, J : Théorie des ondes et des remous qui se propagent le long d'un canal rectangulaire horizontal, en communiquant au liquide contenu dans ce canal des vitesses sensiblement pareilles de la surface au fond, Liouvilles J. Math., Vol. 17, pp.55-108.

13) 長尾昌朋, 後藤智明, 首藤伸夫: 非線形分散波の数値計算, 土木学会, 海岸工学論文集, Vol.32, pp.114-118, 1985.
14) Laitone, E.V. : The second approximation to cnoidal and solitary waves, J.F.M., Vol.9, Part 3, 1960.

15) Nagashima, H. : Deformation of nonlinear shallow water waves, Scientific Paper, Inst. of Physical and Chemical Res., Vol.71, pp.13-44, 1977.

16）岩瀬浩之, 後藤智明, 藤間功二, 飯田邦彦: 染海域におけ る波数分散効果が近地津波の伝播に及ぼす影響に関する 考察，土木学会論文集，II-58，2002.

17) 相田 勇: 1983 年日本海中部地震津波の波源数値モデ ル, 東京大学地震研究所巢報, 59 号, pp.93-104,1984

18）岩瀬浩之, 竹田勝博, 後藤智明: ソリトン分裂波の増幅機 構と数值解析の誤差特性に関する一考察, 海岸工学論文 集, 第 47 巻, pp.21-25, 2000 .

(2001. 2. 19 受付)

\title{
A COMPARATIVE STUDY OF NONLINEAR DISPERSIVE LONG WAVE EQUATIONS FOR NUMERICAL SIMULATION OF TSUNAMI
}

\author{
Hiroyuki IWASE, Toshifumi MIKAMI, Chiaki GOTO and Koji FUJIMA
}

The dispersion relations and the approximate solutions of solitary-wave type are derived for several depth-averaged and depth-integrated nonlinear dispersive long wave equations. Solutions of depth-averaged equations for solitary wave tend to provide steep wave profile with narrow-width and high-wave hight compared with $\mathrm{KdV}$ solution. On the other hand, solutions of depth-integrated equations for solitary wave provide wide wave profile with wide-width and low-hight. On wave deformation and disintegration to the solitons, the difference is quite important. Not only theoretical examinations but also laboratory and numerical experiments show that depth-integrated Peregrine equation and Madsen \& Sørensen equation are suitable for numerical analysis of tsunami. 